\title{
CONTEXTUAL TEACHING AND LEARNING EFECTIVITY FOR INCREASING ABILITY OF OPEN ECONOMIC UNDERSTANDING \\ EFEKTIVITAS CONTEXTUAL TEACHING AND LEARNING DALAM MENINGKATKAN KEMAMPUAN MEMAHAMI PEREKONOMIAN TERBUKA
}

\author{
AHMAD NUZUL \\ SMA Negeri 1 Dagangan Madiun, Jawa Timur, \\ ahmad.nuzul.ponorogo@gmail.com
}

\begin{abstract}
ABSTRAK
Hasil belajar matapelajaran ekonomi belum maksimal karena rendahnya minat siswa dalam mengikuti kelas terseut. Pembelajaran kontekstual dapat diaplikasikan sebagai peningkatan minat siswa terhadap suatu matapelajaran atau materi tertentu. Pembelajaran kontekstual diaplikasikan sebagai langkah peningkatan minat dan hasil belajar mata pelajaran ekonomi siswa kelas XI IPS 1, SMA Negeri 1 Dagangn, Madiun tahun pelajaran 2012/2013. Pendekatan yang digunakan dalam penelitian ini adalah pendekatan kuantitatif, dengan jenis penelitian tindakan. Hasil yang diperoleh yaitu terjadi peningkatan minat dan hasil belajar siswa dalam memahami perekonomian terbuka dengan pendekatan kontekstual.
\end{abstract}

Kata Kunci: Pembelajaran kontekstual, ekonomi terbuka

\section{PENDAHULUAN}

Hasil belajar mata pelajaran ekonomi pada umumnya masih belum memenuhi harapan. Hal ini disebabkan oleh beberapa faktor antara lain: minat belajar siswa masih rendah, kurikulum yang terlalu tinggi, sarana prasarana yang belum memadahi serta kondisi siswa dan guru. Salah satu dari sekian faktor tersebut adalah belum diberdayakannya potensi siswa sehingga hasil pendidikan hanya tampak dari kemampuan siswa menghafal. Walaupun banyak siswa mampu menyajikan tingkat hafalan yang baik terhadap materi yang diterimanya, tetapi pada kenyataannya mereka seringkali tidak memahami secara mendalam substansi materinya.

Salah satu permasalahan yang dihadapi oleh bangsa Indonesia saat ini adalah rendahnya mutu pendidikan. Berbagai usaha telah dilakukan untuk meningkatkan mutu 
pendidikan nasional, diantaranya dalam bidang pengelolaan sekolah, peningkatan sumber daya pendidikan, pengembangan/penulisan bahan ajar, serta pengembangan paradigma dengan metodologi pembelajaran

Pembelajaran kontekstual merupakan sebuah pendekatan pembelajaran yang berpijak pada keinginan untuk menghidupkan kelas dan menekankan pentingnya lingkungan alamiah diciptakan dalam proses belajar mengajar agar kelas lebih hidup dan lebih bermakna karena siswa mengalami sendiri apa yang dipelajari. Kelas yang hidup adalah kelas yang memberdayakan siswa dengan segala aktivitas belajarnya untuk mencapai kompetensi yang diinginkan sehingga diperoleh minat dan hasil belajar siswa yang optimal.

Salah satu indikator pendidikan yang berkualitas adalah perolehan nilai hasil belajar siswa. Penunjang dari indikator di atas yaitu tersedianya sarana dan prasarana pendukung serta kecakapan guru dalam pengelolaan kelas dan penguasaan materi yang cukup memadai.

Proses belajar mengajar diupayakan agar lebih optimal dan menarik dalam benak siswa kelas
XI.IPS.1 SMA Negeri 1 Dagangan Madiun yang kondisi siswanya dari kalangan sosial ekonomi menengah keatas, tingkat intelektualnya cukup, motivasi belajarnya masih kurang dan sarana pendukung pendidikan lainnya masih kurang mencukupi. Pendekatan mengajar yang diterapkan dalam PBM yaitu dengan menggunakan pendekatan kontekstual (Contextual Teaching and Learning / CTL) dimana siswa menggali dan menemukan pokok materi secara kelompok atau individu sehingga siswa lebih tertarik terhadap materi yang telah disampaikan.

Hasil penelitian tindakan kelas ini di harapkan dapat bermanfaat dalam pembelajaran ekonomi , khususnya mendorong guru untuk lebih kreatif dan motivatif dalam memilih model pembelajaran sesuai dengan kondisi, situasi dan dinamika siswa. Pada akhirnya dapat meningkatkan minat belajar dan hasil belajar serta mengoptimalkan kualitas siswa khususnya pada mata pelajaran ekonomi .

\section{Pembelajaran Ekonomi}

Perkembangan ilmu pengetahuan, teknologi dan arus globalisasi telah membawa perubahan di semua aspek kehidupan manusia. Dalam rangka 
menghadapi berbagai permasalahan yang ditimbulkannya, persaingan global dan proses demokratisasi, sangat diperlukan sumber daya manusia yang berkualitas melalui pembaharuan sistem pendidikan dan penyempurnaan kurikulum, termasuk mata pelajaran Ekonomi yang berbasis kompetensi, demokratis dan berwawasan lokal dengan tetap memperhatikan standar nasional.

Pembaharuan kurikulum perlu dilakukan, karena kurikulum Ekonomi yang berlaku selama ini bersifat sentralistik, beban materi kurang memadai, dan cakupan materi tumpang tindih pada satuan pendidikan yang berbeda. Berdasarkan penjelasan ketetapan MPR Nomor IV/1999 bidang pendidikan yang menuntut dilakukannya pembaharuan berupa sistem pendidikan dan peraturan pemerintah nomor 22 tahun 2000 tentang otonomi daerah, perlu dilakukan perubahan yang berupa diversifikasi kurikulum yang memberi kesempatan kepada daerah untuk mengembangkannya dalam rangka melayani keragaman peserta didik dan sarana pembelajaran, diversifikasi jenis pendidikan, sesuai kepentingan daerah
Prospek dan tantangan di masa depan merupakan bagian integral dari globalisasi ekonomi, yang berpengaruh terhadap profesionalisme pengelolaan usaha. Salah satu aspek pengelolaan usaha baik pada sektor formal maupun nonformal adalah kewajiban perusahaan membuat laporan keuangan sesuai dengan besar kecilnya transaksi keuangan suatu usaha. Sebagai bagian ilmu ekonomi yang mempelajari siklus/proses kegiatan dari seluruh transaksi keuangan perlu dilaksanakan di sekolah untuk membangun perpektif pemahaman dan keterampilan Ekonomi.

\section{Tujuan Pembelajaran Ekonomi}

1. Ekonomi merupakan bahan kajian mengenai suatu sistem untuk menghasilkan informasi berkenaan dengan transaksi keuangan. Informasi tersebut dapat digunakan dalam rangka pengambilan keputusan dan tanggung jawab di bidang keuangan baik oleh pelaku ekonomi swasta (Ekonomi perusahaan), pemerintah (Ekonomi pemerintah), ataupun organisasi masyarakat lainnya (Ekonomi publik).

2. Fungsi mata pelajaran Ekonomi pada Sekolah Menengah Atas adalah mengembangkan 
pengetahuan, keterampilan, sikap rasional, teliti, jujur, dan bertanggung jawab.

3. Tujuan mata pelajaran Ekonomi Sekolah Menengah Atas adalah membekali tamatan SMA dalam berbagai kompetensi dasar, agar mereka menguasai dan mampu menerapkan konsep-konsep dasar, prinsip dan prosedur Ekonomi yang benar, baik untuk kepentingan melanjutkan pendidikan ke perguruan tinggi ataupun untuk terjun ke masyarakat, sehingga memberikan manfaat bagi kehidupan siswa.

\section{Model Pembelajaran Konstekstual (CTL)}

Pembelajaran kontekstual adalah suatu proses pendidikan yang bertujuan untuk membantu siswa melihat makna dalam bahan diklat yang mereka pelajari dengan cara menghubungkan dengan konteks kehidupan mereka seharihari. Pembelajaran kontekstual terjadi apabila siswa menerapkan dan mengalami apa yang sedang diajarkan dengan mengacu pada masalah-masalah dunia nyata yang berhubungan dengan peran dan tanggung jawab mereka sebagai anggota keluarga, warga negara, siswa dan tenaga kerja. Untuk mencapai tujuan tersebut, sistem pendekatan kontekstual (Contextual Teaching and Learning ( CTL) akan membantu siswa melalui kedelapan komponen utama pendekatan kontekstual yaitu : melakukan hubungan bermakna, mengerjakan pekerjaan yang berarti, mengatur cara belajar sendiri, bekerja sama, berfikir kritis dan kreatif, memelihara/merawat pribadi siswa, mencapai standart yang tinggi dan menggunakan assesment autenty.

Filosofi pembelajaran kontekstual berakar dari faham progresivisme John Dewey. Intinya siswa akan belajar dengan baik apabila apa yang mereka pelajari berhubungan dengan apa yang telah mereka ketahui serta proses belajar akan produktif jika siswa terlibat aktif dalam proses belajar disekolah.

Selain teori progresivisme John Dewey, teori kognitif melatarbelakangi pula filosofi pembelajaran kontektual. Siswa akan belajar dengan baik apabila mereka terlibat secara aktif dalam segala kegiatan dikelas dan berkesempatan untuk menemukan sendiri. Sejauh ini pendidikan kita masih didominasi oleh pandangan bahwa pengetahuan sebagai perangkat fakta-fakta yang harus dihafal. Kelas masih berfokus pada guru sebagai sumber utama pengetahuan, kemudian ceramah 
sebagai pilihan utama strategi belajar. Untuk itu diperlukan sebuah strategi belajar yang lebih memberdayakan siswa . Sebuah strategi belajar tidak mengharuskan siswa menghafal fakta-fakta, tetapi sebuah strategi yang mendorong siswa mengkonstruksikan pengetahuan dibenak mereka sendiri.

Karakteristik pembelajaran kontekstual menurut Johnson (2002:24) adalah sebagai berikut :

a. Melakukan hubungan yang bermakna ( making meaningful connection ).

b. Melakukan kegiatan-kegiatan yang signifikan ( doing signifikan work).

c. Belajar yang diatur sendiri ( self regulated learning ).

d. Bekerja sama ( collaborating).

e. Berfikir kritis dan kreatif ( critical and creative thinking ).

f. Mengasuh atau memelihara pribadi siswa ( nurturing the individual).

g. Mencapai standar yang tinggi ( reaching high standarts ).

h. Menggunakan penelitian autentik ( using autentik assesment )

Dalam proses pembelajaran guru harus memperhatikan 4 hal (Roestiyah: 1982 ) yaitu mengusahakan keikutsertaan secara aktif siswa, menganalisa struktur materi, menganalisis urutan kerja siswa dan memberi penguatan atau umpan balik. Guru harus meningkatkan minat dan motivasi siswa untuk mencapai hasil belajar yang optimal.

Hasil belajar merupakan salah satu bentuk penilaian dalam pelaksanaan kurikulum (Bahar, 1996 : 13), dengan hasil belajar dapat diketahui keterbatasan belajar siswa dikelas.

Kualitas pendidikan ditentukan oleh beberapa faktor, oleh karena itu pembaharuan di bidang pendidikan sangat diperlukan. Dengan munculnya kurikulum 2004, kurikulum berbasis kompetensi, yaitu pendidikan yang menekankan pada kemampuan yang harus dimiliki oleh lulusan suatu jenjang pendidikan. Kompetensi lulusan suatu jenjang pendidikan sesuai dengan tujuan pendidikan Nasional, mencakup komponen pengetahuan, ketrampilan, kecakapan, kemandirian, kreativitas, kesehatan, akhlak, ketaqwaan dan ke warganegaraan.

Untuk mengoptimalkan pembelajaran diperlukan suatu perubahan pendekatan mengajar secara terus menerus, sehingga mendorong perubahan pola berpikir dan perilaku siswa. Fleksibilitas pembelajaran sangat diperlukan untuk mencapai kompetensi dasar. Strategi pembelajaran yang tepat 
untuk kompetensi dasar ini dipilih strategi pembelajaran dengan pendekatan kontekstual (Contextual Teaching and Learning / CTL ). Pendekatan kontekstual merupakan salah satu pendekatan pembelajaran yang menekankan pentingnya lingkungan alamiah diciptakan dalam proses belajar agar kelas lebih hidup dan lebih bermakna karena siswa mengalami sendiri apa yang dipelajarinya. Proses pembelajaran berlangsung alamiah dalam bentuk kegiatan siswa bekerja dan mengalami. Guru berperan sebagai fasilitator, pembimbing yang memberi kemudahan belajar pada siswanya dan bukan transfer pengetahuan dari guru ke siswa Hasil pembelajaran diharapkan lebih bermakna bagi anak untuk memecahkan persoalan, berpikir kritis dan melaksanakan observasi serta menarik kesimpulan dalam kehidupan jangka panjang. Dalam memperoleh kemampuan belajar siswa diberikan pengalaman belajar secara terus menerus dari yang mudah menuju yang kompleks. Pendekatan kontekstual memungkinkan siswa untuk menguatkan, memperluas dan menerapkan pengetahuan dan ketrampilan akademik mereka dalam berbagai macam tatanan kehidupan di sekolah maupun di luar sekolah. Tugas guru dalam kontekstual adalah membantu siswa mencapai kompetensi dasar, mengelola kelas sebagai sebuah tim yang bekerja bersama untuk menemukan sesuatu yang baru bagi anggota kelas (siswa). Strategi ini kita kembangkan agar pembelajaran berjalan lebih produktif dan bermakna.

Selain pendekatan kontekstual dalam proses belajar mengajar ini diperlukan bahan ajar. Dengan bahan ajar, memungkinkan siswa dapat mempelajari suatu kompetensi dasar secara runtut dan sistematis sehingga secara akumulatif mampu semua kompetensi secara utuh dan terpadu. Bahan ajar merupakan informasi, alat dan teks yang diperlukan guru untuk perencanaan dan penelaahan implementasi pembelajaran.

Dengan strategi pembelajaran dengan pendekatan kontekstual (Contextual Teaching and Learning / $C T L$ ) dapat mengoptimalkan minat belajar siswa terhadap materi pendidikan.

Hipotesis tindakan yang diajukan dalam penelitian tindakan kelas ini adalah : "Ada peningkatan minat dan hasil belajar siswa dalam memahami perekonomian terbuka dengan pendekatan kontekstual (Contextual Teaching and Learning 
/CTL) dalam pembelajaran ekonomi siswa kelas XI.IPS.1 SMA Negeri 1 Dagangan Madiun tahun pelajaran 2012/2013".

\section{METODE}

Penelitian dilaksanakan di kelas XI.IPS.1 SMA Negeri 1 Dagangan Madiun. Kelas yang diteliti adalah kelas XI.IPS.1 yang berjumlah 29 siswa. Subyek peneliti adalah guru kelas pada mata pelajaran ekonomi yang juga sebagai observer (kolaborator).

Penelitian dilakukan selama 2 bulan, yaitu mulai Oktober 2012 sampai Nopember 2012 melalui 2 siklus. Secara umum siklus penelitian ini melalui langkahlangkah kegiatan : 1.Perencanaan. 2.Pelaksanaan. 3.Pengamatan. 4.Refleksi. Setiap siklus berlangsung sesuai dengan jumlah pertemuan dalam sub konsep yang dipelajari.

Tindakan yang dilakukan pada siklus I (pertama) ialah melaksanakan skenario pembelajaran yang terdapat dalam rancangan pembelajaran dan mengamati pelaksanaannya. Pelaksanaan tindakan kelas siklus I ditekankan pada aktivitas siswa dan hasil belajar siswa dengan penerapan (Contextual Teaching and Learning / CTL). Pada akhir tindakan dilakukan evaluasi dan refleksi sebagai masukan untuk melanjutkan siklus II (kedua).

Pelaksanaan siklus II (kedua) berangkat dari hasil refleksi siklus I (pertama). Langkah-langkah siklus II (kedua) seperti halnya siklus I , yaitu: 1.Refleksi siklus I (pertama). 2. Perencanaan tindakan. 3. Pelaksanaan tindakan. 4. Evaluasi dan refleksi.

\section{HASIL DAN PEMBAHASAN}

\section{Siklus I}

Deskripsi dan Data Pelaksanaan Pembelajaran

Pada siklus I (pertama) pelaksanaan tindakan berlangsung satu kali tatap muka selama 2 jam pelajaran. Tindakan kelas yang dilaksanalkan menggunakan pembelajaran dengan pendekatan kontekstual (Contextual Teaching and Learning / CTL ) dengan metode pengamatan dan diskusi. Pada siklus pertama ini tindakan yang digunakan berorientasi untuk melatih siswa agar mampu belajar menemukan, mengamati dan menganalisis hasil observasinya dengan cara bekerja sama dalam menjelaskan tugas secara kelompok dan mengkomunikasikan hasil kerja kelompoknya melalui presentasi hasil pengamatan yang dilakukannya.

Pada kegiatan awal pembelajaran peneliti membagi 
siswa menjadi 9 kelompok (yang sudah ditentukan sebelumnya) dan memberikan lembar kegiatan siswa serta lembar penilaian kinerja (peer assesment) kepada siswa. Kemudian peneliti menjelaskan secara singkat tujuan pembelajaran yang ingin dicapai dan menjelaskan juga langkah-langkah instruksi atau penjelasan awal mengenai tugastugas yang harus dikerjakan oleh masing-masing kelompok. Selanjutnya guru mengajak siswa untuk melakukan pengamatan langsung dengan VCD pembelajaran ekonomi pada standar kompetensi memahami perekonomian terbuka.

Selama kegiatan pengamatan berlangsung, siswa juga melakukan penilaian terhadap aktivitas temannya dengan memberika tanda (V) pada lembar peer assesment yang telah disediakan, sedangkan aktivitas guru diamati oleh observer (kolaborator).

Setelah kegiatan pengamatan selesai, masing-masing kelompok mempresentasikan hasil pengamatannya di depan kelas. Selama presentasi berlangsung terjadi tanya jawab antar kelompok mengenai hasil pengamatannya. Di akhir kegiatan siswa menyerahkan laporan hasil kegiatan dan lembar penilaian ( peer assesment).
Pada kegiatan penutup, peneliti memberi penguatan (reinforcement) atas hasil kegiatan pembelajaran, juga peneliti memotivasi siswa untuk senantiasa mengembangkan kemampuan mendeskripsikan dan mengkomunikasikan hasil pengamatannya.

Beberapa hal penting yang dapat diamati oleh peneliti selama pelaksanaan pembelajaran sebagai berikut : Pertama suasana sedikit ramai ketika berlangsung pengamatan melalui VCD pembelajaran ekonomi diruang. Hal ini terjadi karena ada beberapa siswa masih kurang tahu apa yang harus dikerjakan dan bagaimana yang harus diamati. Kedua, antusiasme siswa dalam kegiatan pengamatan tergolong tinggi, hampir semua siswa mengikuti dengan penuh semangat.Ketiga, pada saat presentasi hasil pengamatan, masih ada sebagian siswa yang masih ragu-ragu atau belum berani mengungkapkan ideidenya secara verbal. Keempat, kegiatan pembelajaran berlangsung dalam waktu yang sangat ketat. Ini memang disayangkan oleh siswa. Siswa merasa terlalu sempit waktunya hingga terkesan tergesagesa. 


\section{Siklus II}

Deskripsi dan Data Pelaksanaan Pembelajaran

Menyikapi hasil analisis siklus I (pertama), tindakan kelas yang dilakukan diantaranya menjaga agar antusiasme siswa dalam mengikuti KBM lebih tinggi, dan meningkatkan kerja sama kelompok serta melatih siswa berkomunikasi/ mengungkapkan pendapatnya secara verbal.

Sebagaimana siklus 1 (pertama), pelaksanaan tindakan pada siklus 2 (kedua) berlangsung dalam dua kali tatap muka selama 2 jam pelajaran. Deskripsi pelaksanaan pembelajaran pada siklus 2 (kedua) sebagai berikut.

Pada kegiatan awal pembela jaran, peneliti mengawali kegiatan dengan apersepsi dan memotivasi siswa. Siswa diminta kembali melakukan pengamatan pada standar kompetensi memahami perekonomian terbuka melalui VCD kemudian mendiskusikan hasil pengamatan dengan kelompoknya. Setelah selesai melakukan pengamatan dan diskusi kelompok, masing-masing kelompok mempresentasikan hasil pengama tannya di depan kelas. Semua kegiatan tersebut dilakukan sebagaimana siklus 1 (pertama), termasuk penilaian kinerja dengan peer assesment (oleh siswa) dan analisis kegiatan guru PTK oleh observer (kolaborator).

Pada kegiatan penutup, peneliti memberi penguatan kembali tentang hasil kegiatan pembelajaran. Juga memotivasi siswa untuk tetap berlatih mempresentasikan hasil pengamatannya.

Peneliti juga menemukan beberapa hal penting selama pembelajaran. Pertama, pada saat pengamatan pada standar kompetensi memahami perekono mian terbuka melalui VCD dan diskusi kelompok, kegiatan berlangsung sebagai mana yang diharapkan, suasana kelas aktif tetapi tidak seramai pada siklus 1 (pertama). Tampak siswa sudah paham akan apa yang harus dikerjakan.Kedua, pelaksanaan presentasi lebih meriah daripada siklus 1 (pertama). Beberapa pertanyaan kritis muncul dan siswa mulai aktif bertanya. Ketiga, penggunaan waktu lebih tertib dan lebih efisien, kesan terburu-buru tidak kelihatan lagi. Itulah beberapa hal penting yang ditemukan dalam pelaksanaan pembelajaran siklus 2 (kedua).

\section{Pembahasan}

Bagian ini akan membahas dan mengkaji hasil-hasil dan temuan penelitian. Hal yang akan dibahas, 
sesuai dengan masalah yang menjiwai penelitian tindakan kelas ini adalah pengoptimalkan minat belajar siswa melalui pembelajaran pendekatan konsep (contextual teaching and learning/CTL).

Aktivitas Siswa dengan

Pembelajaran kontekstual

Dari gambaran hasil penelitian di atas, pelaksanaan pembelajaran dengan menggunakan pendekatan kontekstual /CTL dapat dikatakan berlangsung dengan baik. Artinya tahapan-tahapan pembelajaran dapat terlaksana sesuai dengan rancangan pembelajaran yang sudah direncanakan. Tidak ada tahapan yang tidak dilaksanakan. Dan siswa mengikuti setiap tahapan dengan penuh semangat, dan penuh antusias.

Beberapa masalah yang muncul, seperti suasana kelas sedikit ramai pada saat pengamatan dan diskusi, tidak mengurangi kelancaran pelaksanaan pembelajaran. Semuanya terjadi karena ada beberapa siswa yang kurang memperhatikan penjelasan tentang kegiatan yang harus dikerjakan. Untuk menghindari hal semacam ini guru memang harus menciptakan situasi kelas yang menggiring siswa untuk berkonsentrasi dalam mengikuti aktivitas pembelajaran.
Hal lain yang perlu diingat adalah bahwa setiap model pembelajaran yang baru diterapkan akan senantiasa memunculkan kendala. Situasi psikologis siswa serta rasa asing akan hal-hal baru itu tak jarang memunculkan kesulitan-kesulitan, baik dalam skala kecil atau besar dalam pelaksanaannya.

Masalah ketatnya waktu yang dirasakan oleh siswa merupakan konsekuensi logis akan tuntutan belajar secara aktif dan efisien, sehingga waktu belajar tidak banyak terbuang. Maka bila siswa diajak belajar dengan waktu terbatas mereka terkesan belum siap. Akan sangat baik bila hal semacam itu terus dilatih agar siswa mempunyai kebiasaan belajar dan bekerja sama secara aktif dan efisien.

Tentang antusiasme siswa yang tinggi selama mengikuti pembelajaran, hal ini menunjukkan bahwa pembelajaran dengan pendekatan Contextual Teaching and Learning menaarik perhatian siswa.

Pada siklus 2 (kedua), aktifitas belajar siswa menunjukkan peningkatan walaupun masih digolongkan rendah, siswa mulai berani mengkomunikasikan hasil pengamatannya dan sudah berani mengungkapkan pendapatnya, terutama intensitas dan mutu 
pertanyaan. Indikator yang lainnya juga mengalami peningkatan.

Temuan ini menunjukkan, pembelajaran yang lebih banyak melibatkan siswa dan mengaktifkan siswa seperti Contextual Teaching and Learning dalam pembelajaran lebih disukai oleh siswa. Ini sesuai dengan pendapat Degeng ( 1998 : 23 ) yang menyatakan bahwa penataan lingkungan belajar yang memberikan kondisi bagi adanya keterlibatan siswa sebagai subyek yang belajar sangat diperlukan.

Penelitian tindakan kelas ini juga menemukan bahwa siswa sudah mampu melakukan penilaian terhadap keaktifan temannya dalam proses belajar mengajar. Yang pasti apapun yang diperoleh siswa, melibatkan mereka dalam penilaian akan menjadikan mereka benarbenar sebagai subyek belajar, bukan obyek.

Peningkatan Minat Belajar Siswa

Data hasil belajar siswa menunjukkan, rata-rata minat belajar siswa pada akhir belajar pada siklus 1 (pertama) adalah 67.75. Sedangkan pada siklus 2 (kedua) rata-rata minat belajar siswa 76.10 ini menunjukkan peningkatan minat belajar siswa. Pelaporan tiap kelopok juga menunjukkan hasil yang lebih baik dilihat dari sistematika pelaporan maupun isi pelaporan.

Peningkatan tersebut memberikan bukti bahwa penggunaan CTL dalam pembelajaran dapat secara efektif dapat meningkatkan minat belajar siswa.

Kontribusi penggunaan pembelajaran Contextual Teaching and Learning dalam mengoptimalkan minat belajar siswa dapat ditinjau dari beberapa sudut.

Pertama, dengan mengadakan pengamatan langsung siswa akan mengembangkan pemahamannya dengan baik.

Kedua, presentasi yang dilakukan dapat meningkatkan keterampilan siswa berbicara ( berkomunikasi ) dan mengembangkan kemampuan siswa untuk berpartisipasi penuh dalam forum umum dimana tentang suatu materi pelajaran digunakan.

Ketiga, kegiatan pembelajaran dilaksanakan secara berkelompok, hal ini akan melatih siswa untuk menciptakan masyarakat belajar, sehingga hasil pembelajaran juga dapat diperoleh dari kerjasama dengan orang lain. Dan yang terakhir, dengan melakukan assesment terhadap temannya, mereka dapat mengetahui kekurangan-kekurangan temannya. Dengan begitu, mereka dapat 
melakukan hal yang lebih baik untuk pekerjaannya sendiri.

Dari hasil penilaian diatas maka, hipotesis tindakan yang diajukan dalam penelitian tindakan kelas ini: "Ada peningkatan minat dan hasil belajar siswa dalam memahami perekonomian terbuka dengan pendekatan kontekstual (Contextual Teaching and Learning /CTL) dalam pembelajaran ekonomi siswa kelas XI.IPS.1 SMA Negeri 1 Dagangan Madiun tahun pelajaran 2012/2013"dapat diterima.

\section{PENUTUP}

\section{Simpulan}

Berdasarkan hasil penelitian tindakan kelas (PTK) yang dilakukan, dapat disimpulkan sebagai berikut :

1. Pembelajaran dengan konstektual (Contextual Teaching and Learning) dapat mengoptimalkan minat belajar ekonomi pada standar kompetensi memahami perekonomian terbuka.

2. Pembelajaran dengan konstektual (Contextual Teaching and Learning) dapat meningkat aktifitas siswa dalam kegiatan belajar mengajar ekonomi pada standar kompetensi memahami perekonomian terbuka.

3. Pembelajaran kontekstual (Contextual Teaching and
Learning) dapat meningkatkan aktifitas dan kreatifitas guru dalam proses pembelajaran ilmu pengetahuan sosial (IPS) pada standar kompetensi memahami perekonomian terbuka.

4. Penerapan pembelajaran konstektual (Contextual Teaching and Learning) memberikan peluang kondisi hubungan guru dengan siswa dan siswa dengan siswa lebih dekat sehingga suasana belajar Stress Free dapat tercipta.

\section{Saran}

1. Guru harus memiliki komitmen yang tinggi, kesabaran yang teguh, persiapan yang matang dan kreatifitas yang inovatif dalam melaksanakan kegiatan pembelajaran melalui Contextual Teaching and Learning.

2. Peran guru sebagai motifator, fasilitator dan organisator dalam Contextual Teaching and Learning harus lebih ditonjolkan agar hasil yang diperoleh bisa optimal.

3. Mengingat pembelajaran Contextual Teaching and Learning merupakan gabungan bermacam-maca metode, maka perlu direncanakan penelitian lebih lanjut untuk menguji efektifitas dan efesiensi 
terhadap peningkatan hasil belajar siswa.

\section{DAFTAR PUSTAKA}

Depdikbud. 1999. Bahan Pelatihan Penelitian Tindakan (Action Research).Jakarta: Dirjen Dikdasmen dan Dikmenum. Degeng, I Nyoman Sudana. 1998. Mencari Paradigma Baru Pembelajaran Masalah Belajar: Dari Keteraturan Menuju Kesemrawutan (Pidato Pengukuhan Guru Besar IKIP Malang). Malang.IKIP Malang.

Depdikbud, 1993. Kurikulum Pendidikan Dasar dan
Menengah, Landasan, Program dan pengembangan. Jakarta: Depdikbud.

Depdiknas, 2003.Garis-Garis Besar Program Pengajaran. Jakarta : Depdikbud.

Depdiknas, 2006. Lampiran peraturan menteri pendidikan Nasional No. 22 tahun 2006 tanggal 23 mei 2006 (Perment 22-23,2006)

Herwindo. 1998. Bagaimana Murid Belajar. Jakarta. Dirjen Dikdasmen Depdikbud.

Nurhadi,Dr.MPd. 2004. Pembelajaran Contextual dan penerapannya dalam KBK.Universitas Negeri Malang 